\title{
S
}

\section{INVENTORY AND SURVEY OF THE BROWN AND RAINBOW TROUT POPULATIONS OF THE BIG HOLE RIVER OF SOUTHWEST MONTANA, $2001-2005$.}

By:

Richard A. Oswald

STATE AMAMMENT BOLLECTION

MAY 107006

MONTANA SIAIE LIBKARY

1515 E. 6th AVE.

HELENA. MONTANA 59620

June 2005

Montana Department of Fish, Wildlife \& Parks

Region Three

1400 S. 19th Avenue

Bozeman, Montana 


\section{ACKNOWLEDGMENTS}

The author would like to gratefully acknowledge the able assistance of the following individuals in the collection of field data under often arduous conditions; Scott Lula, Jon Hoerning, Tim Mosolf, Peter LaMothe, Chris Brozell, Scott Opitz, Gary Senger, and Randy Gazda. The author would also like to thank Dick Vincent, Jeff Bagdanov and Jody Hupka for assistance in the analyses of Whirling Disease samples. Finally, the author would like to acknowledge the assistance of Bob McFarland, Reed Simonson, Wayne Black, and Deanna Meredith in data preparation and analysis techniques. 


\begin{abstract}
River discharge and thermal data are summarized for the Big Hole River at the USGS Melrose Gage site for water years 2002 - 2004. A relatively severe episode of drought continued to dominant flow and temperature regimes over the report period. Despite extremely low water yields recorded over the period, summer minimum flows were slightly mitigated through components of a Big Hole River Drought Plan administered by the Big Hole River Watershed Committee. Rainbow trout population studies were conducted by fall population estimates in the Jerry Creek and Melrose Study Sections while brown trout population studies were conducted from spring estimates in the Maiden Rock, Melrose, and Hog Back Study Sections. Rainbow trout populations demonstrated declining trends in recruitment and population density but maintained near average standing crops through relatively high densities if older, larger fish in the populations. A relatively severe point source for whirling disease was identified near the head of the Melrose Section. Data strongly suggest that the whirling disease infection has been reducing rainbow trout recruitment through the reach. Brown trout populations in the Maiden Rock, Melrose and Hog Back Section exhibited declining trends in density, standing crop, recruitment, numbers of older larger fish, and spring condition factor concomitant with extremely low summer flow regimes and high summer water temperatures throughout the period. Record high winter ambient temperatures in January and February of 2005 were associated with extremely high brown trout condition factor. Numbers of Age V and older brown trout in the Maiden Rock Section declined to their lowest observed density since the inception of special angling regulations in 1981 .
\end{abstract}




\section{TABLE OF CONTENTS}

Page

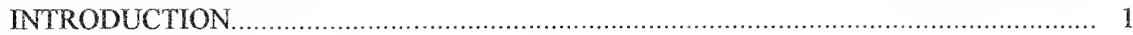

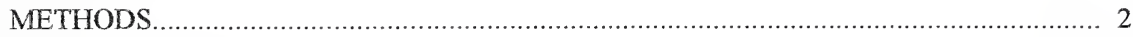

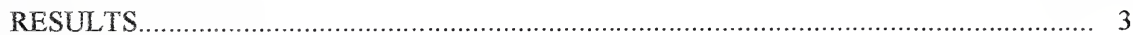

FLOW AND TEMPERATURE REGIMES ...................................................... 3

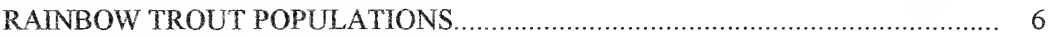

JERRY CREEK STUDY SECTION......................................................... 6

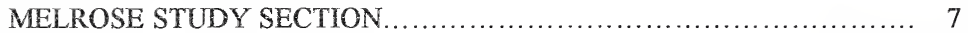

BROWN TROUT POPULATIONS ................................................................. 8

MAIDEN ROCK STUDY SECTION .................................................. 8

MELROSE STUDY SECTION …..................................................... 8

HOG BACK STUDY SECTION........................................................... 9

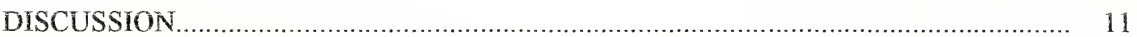

FLOW AND TEMPERATURE REGIMES................................................... 11

RAINBOW TROUT POPULATIONS ....................................................... 13

BROWN TROUT POPULATIONS................................................................ $\quad 14$

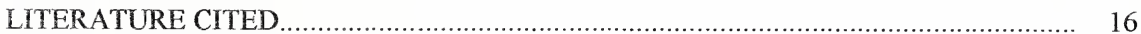

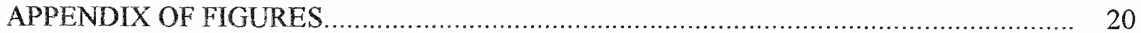




\section{INTRODUCTION}

The Big Hole River is a major tributary of the upper Missouri River drainage in southwest Montana. It merges with the Beaverhead River near Twin Bridges, Montana to form the Jefferson River, one of the three major forks of the Missouri River named by Lewis and Clark. The Big Hole drainage supports native populations of westslope cutthroat and lake trout; Arctic grayling; mountain whitefish; burbot; white, longnose, and mountain sucker; longnose dace; and mottled sculpin. The sport fisheries of the drainage, however, are dominated by introduced populations of rainbow, brown and brook trout which were stocked into the drainage in the late 1930's and early 1940 's. Stocking of hatchery rainbow trout into the Big Hole River and its tributaries was ceased in 1974 in favor of management for wild trout populations.

While the sport fishery of the Big Hole River is dominated by the introduced rainbow and brown trout populations, recent interest in the conservation of native salmonids has expanded research within the drainage. Extensive genetic research has been conducted on tributary populations of native westslope cutthroat trout by Montana Department of Fish, Wildlife and Parks and the Beaverhead National Forest. A native glacial relict population of lake trout in Twin Lakes was studied extensively (Oswald and Roberts 1998) and subjected to genetic testing to confirm its native origins (Oswald 2000c). Liknes (1981) and Oswald (1984) initiated research on the fluvial arctic grayling population of the Big Hole River. Since Oswald (Vincent et al. 1989) last reported on the status of the Arctic grayling population, Arctic grayling research has been conducted under the auspices of the grayling recovery program and reported by Byorth (1991 $1996)$ and, more recently, Magee and Byorth (1998), Magee (1999 and 2002), Magee and Lamothe (2003 and 2004) and Lamothe and Magee (2003 and 2004). For this reason, Arctic grayling population data will not be included or discussed in this report.

The wild brown and rainbow trout populations of the Big Hole River were last described by Oswald (2002) for the Jerry Creek, Maiden Rock, Melrose, and Hog Back study sections. Since the fall of 1999, Big Hole River flow regimes have been dominated by severe drought conditions that have persisted through the winter and spring of 2005. This most recent drought episode followed a very wet climatic period that resulted in extremely high flow regimes during the 1995 - 1997 period. High amplitude and duration of runoff events during this period significantly modified the geomorphology of the Big Hole River channel and trout habitat niche provided therein, at least on a localized basis. Abundant flow regimes also maximized trout habitat niche quantity and quality resulting in brown and rainbow trout populations marked by high standing crops and high densities of older, larger fish (Oswald 2000a and 2002). Subsequent low flow regimes and high summer water temperatures resulted in declines in brown and rainbow trout populations. These declines were largely manifest in brown trout populations as substantial declines in stranding crop and numbers of larger, mature fish (Oswald 2002).

Drought conditions in the late 1980's and early 1990's precipitated a cooperative effort between sportsmen and irrigators under which irrigation withdrawal was mitigated and the river was closed to angling as defined low flow triggers were encountered. Subsequent efforts of the Big Hole River Watershed Committee, a citizen based advocacy group, have expanded and refined drought mitigation efforts into a drought response plan that was adopted for use under future drought conditions. Montana Fish, Wildlife and Parks currently cooperates with the Big 
Hole Watershed Committee in the application of this drought response plan throughout three defined river reaches.

Whirling disease, caused by infections of the protozoan parasite, Myxobolus cerebralis, was discovered in yearling rainbow trout from the Big Hole River in 1996. Subsequent research suggested that the disease has remained present at a relatively low frequency of infectivity within the trout populations and relatively low grade of infection among individual fish (Oswald 2002). Recent studies, however, have identified a localized infection that appears to have affected rainbow trout recruitment in the Melrose Study Section reach. These studies will be discussed in this report.

Angler use of the Big Hole River increased markedly during the 1990's. Angling pressure increased from an estimated 51,203 angler days in 1991 to an estimated 83,408 angler days in 1997 and 79,747 angler days in 1999 (MFWP 1991, 1997 and 1999). While resident angler pressure increased $22.6 \%$ between 1991 and 1997, nonresident angler use increased 158\%. Nonresident anglers composed $47.1 \%$ and $39.0 \%$ of the estimated use in 1997 and 1999 , respectively. This rapid increase in pressure led to the 1999 formation of a citizens advisory committee which studied the issue of crowding on the Big Hole River at the request of the Montana Fish, Wildlife and Parks Commission. One aspect of study included summer user surveys in 1999 and 2000 that gathered data on the demographics and use patterns of anglers and other users of the Big Hole River. As a result of these studies and recommendations from the citizen's advisory committee, the Commission enacted a "Biennial Rule" which placed restrictions and limitations on anglers, commercial outfitters, and other recreational users of the Big Hole River in 2001 and 2002. The Bieenial Rule was extended by the Fish Wildlife and Parks Commission through 2004 and modified slightly in 2005. Since the "Biennial Rule" went into effect, angler use of the Big Hole River has declined substantially. These declines in angling pressure, however, were also accompanied by drought induced low flow regimes and high summer water temperatures, declines in trout populations, and a drought based angling closure in 2000 . The pressure estimates generated in 2001 exhibited a substantial decline to 33,121 angler days but rebounded in 2003 to 57,285 angler days (MFWP 2001 and 2003). The 2001 declines were similar to those observed in other drought impacted southwest Montana rivers. Despite the recent declines in total angling pressure on the Big Hole River, nonresident angler participation continued to increase at $61.5 \%$ of the total use in 2001 and $49.2 \%$ in 2003 .

\section{METHODS}

Trout populations were sampled through the use of electrofishing techniques based on mark-recapture methodologies described by Vincent (1971). Electrofishing was conducted via boat mounted, mobile anode techniques which utilize a 3500 watt generator and Leach type rectifying box. A straight or continuous wave DC current was used at 1,000 to 1,500 watts. Fish captured within the field were drawn to the boat, netted, and deposited into a live car. Individual fish captured were anesthetized, segregated by species, measured for length and weight, marked with a small identifying fin clip, and released. Arctic grayling captured during the sampling are also implanted with an individually numbered Visual Implant (VI) Tag for future identification. Scale samples for age determination were collected from a representative subsample by length 
group. Multiple marking runs and recaptures runs were made through each of the study sections until predetermined goals were achieved in mark and capture totals.

Trout population statistics were analyzed under a log-likelihood methodology developed and described by Montana Fish, Wildlife and Parks (1994) under guidelines presented by Brittain, Lere, and McFarland (1998). Population statistics calculated by the program include density by length and age class, standing crop, condition factor $(\mathrm{K})$, length frequency, and mean length and weight. Statistical analyses are conducted at the P .05 confidence level. Population estimates were calculated for brown trout from March samples collected from the Maiden Rock, Melrose, and Hog Back study sections while rainbow trout population estimates were calculated from September samples collected from the Jerry Creek and Melrose study sections. The seasonal segregation of brown and rainbow trout population estimates was applied to avoid estimate bias due to spawning movements and migrations.

Flow and temperature data were gathered at the Melrose Gage (USGS 2000-2001), by water year, for the report period. Additional stream gages have recently been installed through the Big Hole Watershed Committee's actions to gather additional data on summer stream flow characteristics. Data presented in this report, however, were limited to the Melrose Gage site because it has been operated from 1923 through the present.

Whiling disease test samples were collected via the placement of test cages containing approximately 50 rainbow trout swim-up fry per cage. Strategic placement of 7 test cages in both channels of the Big Hole River and Camp Creek in the Melrose, Montana vicinity was calculated to reveal a point source for the disease and eliminate other potential point sources. Cages were also fitted with recording thermographs and exposed to streamflow for 10 day intervals. After exposure, test cage fish were reared in a FWP isolation laboratory for approximately 120 to 150 days, after which the fish were sacrificed and subjected to histological examination to determine the frequency and grade of infection by standard methods of analysis. Test cages were placed in the Melrose vicinity in 2003 and 2004.

\section{Flow and Temperature Regimes}

\section{RESULTS}

Dominant annual flow regimes (Figure 1) adequately depict the drought conditions which began to influence summer flows in 1999 and dominated the Big Hole River for the 2000 through the 2004 water years. Low mountain snowpack and summer precipitation (National Weather Service Data, Great Falls, MT) resulted in low runoff peaks (Figure 2) which were generally of short duration while annual water yield often barely exceeded 400,000 acre feet per year. While some improvement was noted in the 2002 and, particularly, the 2003 water years, annual water output remained far below the long term average. Spring runoff events also tended to remain below average with the marked exception of 2003 which exhibited a relatively high runoff peak. Annual water yield and peak runoff for 2004 returned to low drought influenced levels typical of the period. Despite some improvement in the 2002 and 2003 water years, base summer flow regimes continued to drop well below recommended minimum flows and long term averages. Mean August streamflow (Figure 3), remained far below the long term average of $461 \mathrm{cfs}$ for that month and also remained below the Wetted Perimeter (WETP) recommended minimum instream 
flow in a chronic fashion during the month of August through the 1999 - 2004 period (Figure 4). Instream flow requirements for aquatic organisms have been calculated at $650 \mathrm{cfs}$ to maintain optimum habitat and $260 \mathrm{cfs}$ to maintain minimum habitat conditions (MFWP 1989). Summary flow statistics for the $1989-2004$ period are presented in Table 1 .

Table 1. Average daily flow statistics for the Big Hole River at the USGS Melrose Gage for the 1989 - 1999 period of record.

\begin{tabular}{|c|c|c|c|c|}
\multicolumn{1}{c}{} & $\begin{array}{c}\text { Runoff } \\
\text { Peak Flow } \\
\text { Water Year }\end{array}$ & $\begin{array}{c}\text { July } \\
\text { Minimum Flow } \\
(\text { Cfs })\end{array}$ & $\begin{array}{c}\text { August } \\
\text { Minimum Flow } \\
\text { (Cfs) }\end{array}$ & $\begin{array}{c}\text { Annual } \\
\text { Water Yield } \\
\text { (Acre - feet) }\end{array}$ \\
\hline 1989 & 3,660 & 441 & 185 & 486,700 \\
\hline 1990 & 3,130 & 385 & 228 & 518,100 \\
\hline 1991 & 9,710 & 450 & 175 & 646,500 \\
\hline 1992 & 1,710 & 421 & 178 & 393,900 \\
\hline 1993 & 4,910 & 982 & 674 & 716,200 \\
\hline 1994 & 3,150 & 272 & 152 & 439,800 \\
\hline 1995 & 11,300 & 983 & 342 & 954,200 \\
\hline 1996 & 11,600 & 606 & 320 & $1,199,000$ \\
\hline 1997 & 12,800 & 1,010 & 514 & $1,352,000$ \\
\hline 1998 & 4,980 & 866 & 299 & 934,400 \\
\hline 1999 & 6,830 & 407 & 228 & 767,900 \\
\hline 2000 & 2,420 & 192 & 126 & 407,700 \\
\hline 2001 & 2,440 & 280 & 151 & 408,800 \\
\hline 2002 & 5,240 & 381 & 197 & 521,000 \\
\hline 2003 & 9,110 & 272 & 184 & 635,400 \\
\hline 2004 & 2,180 & 325 & 157 & 412,200 \\
\hline
\end{tabular}

Low flow regimes during the recent drought influenced period were often accompanied by elevated daily thermal regimes (Figure 5) which soared to record highs in the summer of 2003. The July 2003 maximum temperature of 24.0 degrees C. equaled the prior drought influenced high observed in 1994 while the mean monthly temperature of $19.5 \mathrm{C}$. was the highest observed over the $1985-2005$ drought influenced period. July temperatures in 2002 and 2004 also 
remained high with maxima of 23.5 and means of 18.0 degrees $\mathrm{C}$. recorded in each of the two years. The influence of temperature on aquatic organisms is often highly affected by time duration relationships. The number of days in which water temperatures equaled or exceeded $21.1 \mathrm{C}$ (70.0 F) at the Melrose Gage in July and August is portrayed in Figure 6. July maxima exceeded 21.1 degrees C. (70 degrees F.) at the USGS Melrose Gage on 22 days in 2003 and 18 days in 2004. July and August totals for 2003 resulted in an observed record high of 34 days while the 2004 total of 23 days equaled the previous drought influenced high observed in 1988. Thermal summary statistics for July and August at the USGS Melrose Gage site are presented in Table 2.

Table 2. Temperature range and mean daily temperature in degrees Centigrade for July and August measured at the USGS Melrose gage for the $1989-2004$ period of record.

\begin{tabular}{|c|c|c|c|}
\hline \multirow{2}{*}{ Year } & \multicolumn{2}{|l|}{ JULY } & AUGUST \\
\hline & Max. & Mean & Max. \\
\hline
\end{tabular}

\begin{tabular}{|l|l|l|l|l|l|l|l|}
\hline 1989 & 23.5 & 13.0 & 18.0 & & 21.5 & 10.5 & 16.5 \\
\hline 1990 & 23.0 & 13.0 & 17.5 & & 22.5 & 12.0 & 16.5 \\
\hline 1991 & 23.0 & 12.5 & 18.0 & & 21.5 & 14.0 & 18.0 \\
\hline 1992 & 22.5 & 12.5 & 16.5 & & 23.0 & 8.0 & 17.0 \\
\hline 1993 & 19.5 & 10.5 & 14.0 & & 20.5 & 10.0 & 15.0 \\
\hline 1994 & 24.0 & 10.5 & 17.5 & & 22.5 & 11.5 & 17.5 \\
\hline 1995 & 20.5 & 11.5 & 16.1 & & 21.0 & 12.0 & 16.4 \\
\hline 1996 & 23.0 & 13.5 & 17.7 & & 21.0 & 11.0 & 16.5 \\
\hline 1997 & 21.5 & 10.0 & 16.5 & & 21.0 & 13.0 & 16.5 \\
\hline 1998 & 23.5 & 15.0 & 18.5 & & 23.0 & 13.0 & 17.1 \\
\hline 1999 & 21.5 & 11.0 & 16.5 & & 21.5 & 13.0 & 17.5 \\
\hline 2000 & 23.0 & 11.5 & 17.5 & & 22.5 & 12.5 & 17.0 \\
\hline 2001 & 23.2 & 12.7 & 17.6 & & 23.2 & 12.8 & 18.2 \\
\hline 2002 & 23.5 & 14.0 & 18.0 & & 20.5 & 11.0 & 16.0 \\
\hline 2003 & 24.0 & 14.5 & 19.5 & & 23.0 & 13.5 & 18.5 \\
\hline 2004 & 23.5 & 13.0 & 18.0 & & 22.0 & 11.5 & 17.0 \\
\hline
\end{tabular}




\section{$\underline{\text { Rainbow Trout Populations }}$}

Jerry Creek Section: Rainbow trout studies were initiated in the Jerry Creek study section in the fall of 1986. Trends in estimated rainbow trout density and standing crop for Age I and older fish are presented in Figure 7 for the 1986-2004 period. No electrofishing was conducted in 1994 and 2000 due to low flow and high water temperature in keeping with the Big Hole River Drought Plan and subsequent closures of angling. Rainbow trout densities have exhibited a lineal declining trend since 2001. The 2004 population estimate of 1,372 rainbow trout per mile compared with a long-term study section mean of 1,662 fish per mile. Despite chronic drought conditions and the declines in density, however, standing crop remained relatively stable. The 2004 population estimate revealed a rainbow trout standing crop of 1,002 pounds per mile that was slightly above the long-term study section mean of 951 pounds per mile. While rainbow trout density declined and standing crop remained relatively stable, neither parameter approached observed minima or maxima for the study section. Oswald (2002) observed that the 2001 rainbow trout population in the Jerry Creek Section expanded to a relatively high density of 2,119 fish per mile and an extremely high standing crop of 1,190 pounds per mile. The 2001 standing crop was the highest observed in the sampling history of the Jerry Creek Study Section and obviously combined a relatively strong recruitment class with strong survival of high numbers of older, larger fish in the population despite persistent drought conditions. Peaks in rainbow trout population have typically been associated with strong recruitment cohorts of Age I rainbow trout (Figure 8). The recent trend in recruitment mimics the lineal declining trend in rainbow trout population density. The 2004 estimate of Áge I rainbow trout of 254 fish per mile approaches lows observed in 1996 and 1997. Oswald (2002) observed that poor recruitment of yearling rainbow trout observed in 1992, and 1996-1998 was associated with runoff peaks of $9,700 \mathrm{cfs}$ and higher. The low yearling recruitment of 2004 followed the 2003 runoff peak of $9,110 \mathrm{cfs}$. Poor recruitment of yearling rainbow trout into the population between 1995 and 1998 was directly correlated with rainbow trout population declines over that period.

Prior population analyses (Oswald 1984 and 1986, Vincent et al. 1989, and Oswald 2000a) considered 13 inch and larger and 16 inch and larger rainbow trout numbers as valid parameters for the assessment of the special angling regulations which have been in affect in the river reach which encompasses the Jerry Creek Section since 1988. The two length groups also roughly describe the Age III and older and Age V and older segments of the rainbow trout population. Numbers of 13 inch and larger rainbow trout (Figure 9) experienced a declining trend in 2002 and 2004 but rebounded to an estimated density of 591 fish per mile in 2004 . The densities of these Age III and older fish apparently increased in response to the two relatively strong recruitment classes of yearlings in 2001 and 2002. The 2004 estimate of 13 inch and larger fish compared favorably with highs observed in the 1995 - 1997 period and 2001 that approached or exceeded 600 fish per mile. Densities of 16 inch and larger rainbow trout are depicted in Figure 10. Numbers of these Age $\mathrm{V}$ and older fish had declined in 2002 as a result of poor yearling recruitment years in the 1995 - 1997 but expanded rapidly in a steep, linear fashion through 2003 and 2004. The 2004 estimate of 60 sixteen inch and larger rainbow trout was the second highest observed in the sampling history of the study section. Strong numbers of 13 inch and larger and 16 inch and larger rainbow trout can be directly correlated with the relatively stable standing crop 
observed over the reporting period despite the declining trends in rainbow trout density and recruitment and the persistence of chronic drought conditions.

Melrose Section: Rainbow trout population studies were initiated in the Melrose Section in 1965. Current trends in Age I and older rainbow trout population density and standing crop are depicted in Figure 11 for the $1981-2004$ period of study. Recent trends in rainbow trout density and standing crop are indicative of a population in decline. The 2004 population estimate of 309 Age I and older fish per mile was the second lowest observed over the 1981-2004 period and compared poorly with the long-term study section mean of 566 fish per mile. The 2004 standing crop estimate of 327 pounds per mile approximates population lows observed over the 1981 1983 period but remained above the record low of 217 pounds per mile observed in 1998. Declines in the rainbow trout population can be directly correlated with extremely poor recruitment of yearling fish into the population (Figure 12) over the recent past. With the exception of an extremely strong recruitment spike in 1999, observed yearling rainbow trout recruitment in the Melrose Section has been very poor since 1997, generally approximating about 100 fish per mile. The 2004 population estimate dropped to an observed modern low for the study section of 57 fish per mile.

Recent rainbow trout population declines in the Melrose Section have occurred in conjunction with chronic drought conditions that have affected other trout populations in the Big Hole River. Declines in rainbow trout in the Melrose Section, however, do not parallel those observed in the Jerry Creek Section and appear to be more strongly related to chronic shortfalls in recruitment. Declines in rainbow trout recruitment in the Melrose Section were accompanied by increases in cranial deformities consistent with external symptoms of whirling disease (Warren 1991). These observations led to the initiation of a series of test cages in the Melrose vicinity in the spring of 2003 and 2004. Live cages containing approximately 50 rainbow trout swim up fry and a recording thermograph were exposed to Big Hole River flow for 10 day increments. The cages were placed strategically to test both channels of the river and all tributary input from immediately upstream and throughout the Melrose Study Section reach. Cage studies in 2003 isolated the source of the whirling disease as Camp Creek, a small tributary stream entering the Big Hole from the Highland Mountains approximately 0.25 miles downstream from Melrose, Montana at river mile 39.1. The 2003 study revealed that a cage placed in Camp Creek yielded an average histology of 4.34 for whirling disease. The standard whirling disease histology scale ranges from 0 to 5.0 with increasing severity of tissue damage (Vincent et al. 2005). Of 46 rainbow trout analyzed from the cage, 18 exhibited histology grade 4 and 25 exhibited a grade 5 infection. The 2004 test cages further isolated the point source into Camp Creek as a pasture drain ditch that had been impounded by the landowner into a private fish pond. The cages placed in Camp Creek and the outlet of the private drain ditch complex exhibited averaged histologies of 5.00 and 4.88 respectively while a test cage placed upstream from the mouth of the drain ditch in Camp Creek revealed an average histology of 0.41 . As was the case in the 2003 samples, 33 of 33 fish in the lower Camp Creek cage exhibited a grade 5 infection while 40 of 41 fish sampled in the drain ditch outlet cage exhibited a grade 5 infection. A cage placed in the Big Hole River approximately 0.75 miles downstream from the mouth of Camp Creek exhibited an average histology of 3.89 with 31 of 44 fish tested exhibiting grade 4 or grade 5 level tissue damage. 
Numbers of 13 inch and larger rainbow trout (Figure 13) remained relatively robust in the 2002 and 2003 samples but declined to a density of 206 fish per mile which approximates the period mean of 213 per mile. Numbers of 16 inch and larger rainbow trout (Figure 14) remained stable at relatively low densities approximating 40 fish per mile over the $2002-2004$ period. Densities of these Age V and older fish generally maintained at much higher levels over the 1989 - 1999 period. Current data suggest that numbers of both the $13 \mathrm{inch}$ and 16 inch and larger component of the Melrose Section rainbow trout populations have maintained at relatively stable densities over the current reporting period based on the last substantial recruitment of yearlings into the population in 1999. The dearth of significant recruitment since 1999 will likely result in substantial decreases in the density of older fish and rainbow trout standing crop in the near future.

\section{Brown Trout Populations}

Maiden Rock Section: Brown trout population studies were initiated in the spring of 1981 and continued annually through 1998 to assess the affects of special angling regulations which included implementation of a "slot limit" and gear restrictions. Affects of the special regulations have been evaluated in detail by Oswald (1986), Vincent et al. (1989), and Oswald (2000a). Brown trout populations and standing crops demonstrated an expanding trend from 1981 through the 1998 and 2001 samples. Populations increased markedly after 1984, declined somewhat during the 1989-1992 drought influenced period, and recovered to observed high densities over the 1993-1998 period. The prior population sample in 2001, coupled with the 1998 sample, represented observed highs for the study section in both density and standing crop. Samples collected in 2002 and 2004 exhibited a declining trend in brown trout density and standing crop (Figure 15) similar to those observed in downstream study sections.

Numbers of 13 inch and larger brown trout (Figure 16) increased markedly to exceed 1,000 fish per mile in 1998 following abundant water years in the 1995 - 1997 period. Despite recent drought conditions, densities of 13 inch and larger fish remained above 1,000 fish per mile in 2001 but declined in 2002 and 2004 to less than 800 fish per mile. In contrast, numbers of 18 inch and larger brown trout (Figure 17) declined markedly between the 1998 and 2001 samples and continued these declines in a very steep linear fashion through the 2002 and 2004 samples. The 2004 estimated density of these Age V and older fish was the lowest on record for the Maiden Rock Section since the spring of 1981, prior to the initiation of the special angling regulations.

Melrose Section: Age II and older brown trout population densities and standing crops of the Melrose Section are exhibited in Figure 18 for the 1981-2005 period. The 2002-2005 period exhibited a declining trend in both the density and standing crop of brown trout from highs observed in the 2000 and 2001 samples in the Melrose Section. Most of the decline in both parameters, however, occurred from the 2001 to the 2003 samples with both density and standing crop remaining relatively stable through the 2003 - 2005 samples. Despite the declines,

population density in the Melrose Section remained near the period average of 944 at 906 fish per 
mile and standing crop remained near the period average of 947 at 931 pounds per mile in the 2005 sample. Despite persistent drought conditions, brown trout population density and standing crop in the Melrose Study Section have remained at levels higher than or equal to samples influenced by the $1987-1994$ drought period. Some of the stability observed in population density was related to relatively stable recruitment of Age II brown trout (Figure 19) at relatively low to moderate levels over the $2002-2005$ period. The trends in Figure 19 suggest that recruitment of Age II fish into the Melrose Section population has fared well following strong flow regimes in the early 1980 's and late 1990's as exemplified by the $1983-1986$ and 1999. 2001 samples. Conversely, Age II recruitment has fared poor in the $1989-1997$ and $2002-2004$ samples influenced by low flow regimes. The slight improvement in brown trout population density in 2005 was directly related to the improvement in Age II recruits to 260 fish per mile.

Numbers of 13 inch and larger brown trout (Figure 20) have exhibited a declining trend from highs observed in 2000 and 2001. Despite the declining trend, however, the 2005 sample remained statistically identical (P .05) to the sample period mean of 604 at 597 fish per mile. Record high densities of 18 inch and larger brown trout in the 2000 - 2001 samples in the Melrose Section (Figure 21) remained relatively high at about 80 fish per mile in the 2002 sample but continued a trend of decline from 2000 into the 2003 sample. Densities of these Age V and older fish then exhibited a relatively stable trend through the $2003-2005$ period at approximately 40 fish per mile. Densities of 18 inch and larger brown trout approximating 40 fish per mile generally represented highs recorded in the early 1980's in the Melrose Section as special slot limit regulations were applied to upstream environments and high densities of the drought influenced 1989 - 1993 samples. Densities of Age V and older brown trout approximating 40 fish per mile are not representative of the density potential of the river reach observed following the high flow regimes of the late 1990's.

Mean spring brown trout condition factor $(\mathrm{K})$, particularly that of the older, larger fish in the population, has been observed to decline with low flow conditions in many southwest Montana river fisheries (Oswald 2000b and 2003). A comparative depiction of spring brown trout condition is presented in Figure 22 in terms of the sample population mean, the mean $\mathrm{K}$ for Age IV and older fish, and mean $\mathrm{K}$ for Age $\mathrm{V}$ and older fish. The comparison was made between three relatively good flow years $(1993-1997)$ and three relatively low flow years $(2001-2003)$ and includes the 2005 sample means. The comparisons in Figure 22 suggest that brown trout condition for the overall population fared better under good flow regimes than it did under low flows. This relationship was enhanced when only Age IV fish were considered in the analysis and was stronger still when considering only the Age V and older segment of the population. The 2005 sample represented an anomaly to the trend presented in the graph in that spring brown trout condition was exceptionally high despite continued drought conditions and low flow regimes. This anomaly was probably associated with exceptionally mild overwinter thermal conditions as record high ambient winter temperature regimes for Montana were observed for the months of January and February (U.S. National Weather Service data, Great Falls).

Hog Back Section: The Hog Back study section was initiated in the spring of 1987 in order to monitor the brown trout dominated lower reaches of the Big Hole River (Vincent et al, 1989). Brown trout population trends for the Hog Back Section were last discussed by Oswald 
(2002). Estimated spring densities and standing crops of Age II and older brown trout are presented in Figure 23 for the sample period. Following recorded highs in density and standing crop observed in 1997 and 1998, brown trout populations have exhibited a general trend of decline over the 1999 - 2005 period. Although brown trout density increased slightly in 2001 and 2002 based on two relatively strong recruitment classes Age II fish, (Figures 24 and 25) the 2003 -2005 resulted in record low densities for the $1987-2005$ period of study. The 2004 sample revealed a slight improvement in density and standing crop from the 2003 sample with another slight improvement in recruitment of Age II fish but the improvement was temporary as the 2005 samples again revealed a brown trout standing crop statistically identical (P .05) to the 2003 sample at about 520 pounds per mile and revealed a record low density of 450 Age II and older brown trout per mile. With the slight exceptions of 2002 and 2004, the observed declines in brown trout standing crop from observed maxima in 1998 and 1999 have been relatively steep and linear. Similar declines were observed following low flow regimes in the 1987 - 1990 period and the 1991 - 1995 periods. Conversely, observed highs in standing crop occurred following abundant flows in the 1982 - 1986 and 1995 - 1998 periods and relatively ample flows in 1990 and 1991. Low standing crops of about 520 pounds per mile in the 2003 and 2005 samples suggest that drought based population declines might have stabilized at minimal population levels for the river reach. The 2005 density estimate of 450 Age II and older brown trout per mile was the lowest observed for spring brown trout populations in the Maiden Rock, Meirose, and Hog Back Study Sections. Recruitment of Age II brown trout into the Hog Back population (Figure 24) exhibited a general trend of decline from about 500 fish per mile observed in the 2001 sample. While recruitment remained relatively strong in 2002 and showed some recovery in 2004, the 2003 and 2005 Age II brown trout estimates of 192 and 116 per mile were relatively weak for the reach with the 2005 recruitment representing the second lowest density observed for the study section. Strong recruitment in the 2001 and 2002 samples was accompanied by a steep decline in the numbers of Age V and older brown trout in the Hog Back Section (Figure 25). This data and similar data from other southwest Montana rivers strongly suggest that despite chronic drought conditions, a steep decline in the numbers of older, larger brown trout could temporarily reduce competition in the population resulting in more favorable conditions for the survival and recruitment of juvenile fish (Oswald 2003).

Estimated densities of 13 inch and larger brown trout in the Hog Back Section (Figure 26) have varied over the study period in a manner quite similar to the trends of the brown trout population. Numbers of these Age III and older brown trout have exhibited a strong declining trend from the record high observed in 1998 to record low densities for the study section of 365 and 316 per mile observed in 2003 and 2005. Slight improvements in 13 inch and larger brown trout densities in 2002 and 2004 were associated with the relatively strong recruitment of Age II fish (Figure 24) in 2001 and 2002. Similar declines in 13 inch and larger brown trout were observed with low flow regimes in the 1987 - 1990 period and the 1991 - 1995 periods. Conversely, highs in these Age III and older fish were observed following abundant flows in the 1982 - 1986 and 1995 - 1998 periods and relatively ample flows in 1990 and 1991. Estimated densities of 18 inch and larger brown trout (Figure 27) steadily declined to a low of 18 fish per mile observed in the 2003 sample since the observed high for the study section was recorded in 1998. Low densities near 20 fish per mile were also observed in the late 1980's and early 1990's 
samples in association with drought influenced low flow regimes. A slight upward trend to 34 and 39 fish of these Age V and older fish per mile was observed in the 2004 and 2005 samples despite continued low flow regimes. This trend was substantially different from those observed in the Maiden Rock and Melrose Sections and was associated with improved survival of Age II recruits in 2001 and 2002 which would have contributed surviving Age V and VI fish in the 2004 and 2005 samples. Despite the improved numbers of 18 inch and larger brown trout in the 2004 and 2005 samples, relative densities of Age II fish in the 2001 and 2002 appeared to suggest higher expected stock densities of Age $\mathrm{V}$ and older brown trout than those actually observed in the samples. This suggests that survival of fish from Age II to Age V and older was probably compromised by low flow regimes that dominated the recent sample period. Conversely, record warm winter temperatures in January and February 2005 (National Weather Service data, Great Falls) might also have contributed to slightly improved over-winter survival of these mature fish.

Similar to the analysis for the Melrose Section, a comparative analysis of mean spring brown trout Condition Factor (K) (Figure 28) was conducted for the Hog Back Section. Mean K for the total Age II and older brown trout sample, for the Age IV and older segment of the population, and for the Age $\mathrm{V}$ and older segment was compared for 4 high flow regime years (1995 - 1998) versus 4 low flow regime years $(2000-2003)$ and the 2005 sample. As was the case in the Melrose Section, mean $\mathrm{K}$ was substantially high for the high flow period when compared with the low flow period. The difference was more pronounced than that observed for the Melrose Section and was, again, most pronounced for the older brown trout. As was also the case for the Melrose Section, the 2005 spring Hog Back sample yielded mean Condition Factors higher than those observed in the abundant flow years with the exception of the highest value observed in 1998 for the Age $\mathrm{V}$ and older fish. Mean spring 2005 brown trout $\mathrm{K}$ values for the Melrose and Hog Back Sections were extremely similar. The data strongly suggest that, despite persistent drought conditions, record high ambient January and February air temperatures resulted in much higher than average spring brown trout condition factor in the Hog Back Section.

\section{DISCUSSION}

\section{Flow and Temperature Regimes}

Annual water yield, spring runoff peaks, and summer minimum flows and water temperatures in the Big Hole River, over the current portions of this report period, continued to be dominated by drought conditions marked by below average mountain snowpack, below average spring and summer precipitation, and high ambient summer air temperatures. These conditions were consistent with warmer than average (El Nino) sea temperatures in the Pacific Ocean which consistently result in below average precipitation and above average air temperatures east of the Continental Divide in Montana (National Weather Service, Great Falls). Oswald (2002) concluded that drought influenced conditions on the Big Hole River persisted over the 1999 through 2001 period resulting in a below average flow pattern which exhibited some of the lowest annual water yields observed for the period of record at the USGS Melrose Gage. Despite the exceptionally low water yields in 2000, 2001 and 2004, summer minimum flows have 
been substantially improved when compared with other severely impacted drought years such as 1987,1988 , and 1994. Summer flows in 1988 dropped to a minimum of $53 \mathrm{cfs}$ at the Melrose Gage while minimum flows of $126 \mathrm{cfs}$ in $2000,151 \mathrm{cfs}$ in 2001, and $157 \mathrm{cfs}$ in 2004 were maintained despite annual water yields which dropped below that observed in 1988. This improvement can be directly correlated with components of the Big Hole River Drought Plan such as the voluntary irrigation cutbacks and the restriction of domestic diversion as the $150 \mathrm{cfs}$ flow trigger is encountered. While small improvements in annual water yield marked the 2002 and 2003 Water Years, summer base flows generally remained well below the minimum recommended flow of $260 \mathrm{cfs}$ at the Melrose Gage. Flows below Wetted Perimeter minima usually reduce the carrying capacity of streams (Nelson 1980 and 1980a). As wetted perimeter declines below the recommended minima, losses in primary and secondary production, cover, spawning habitat, and movement corridors can all affect trout habitat niche abundance and diversity. Trout population data for the Big Hole River strongly suggest that persistent flows below the Wetted Perimeter recommended minimum have resulted in substantial reductions in trout standing crop and numbers of large trout (Vincent et al. 1989, Oswald 2000a and 2002). Similar reductions in biomass and large trout numbers were also observed on the Beaverhead and Ruby Rivers (Oswald and Brammer 1993, Oswald 2000c and 2003) when minimum flows declined below the Wetted Perimeter recommendation. Data also suggest, however, that the moderate runoff events of the drought periods often resulted in strong, if not exceptional recruitment of juvenile rainbow trout into the population (Oswald 2000a and 2002). Low spring runoff peaks are also often characteristic of drought influenced flow regimes. While runoff peaks during the $1995-1997$ period remained strong on an annual basis, spring runoff events in 2000, 2001, and 2004 were far below average. Dominant discharges associated with spring runoff events usually determine channel morphology and often the associated habitat niche diversity (Hunter, 1991). They are also the method under which channels flush accumulated sediment bedload and maintain gradients consistent with valley floors of origin (Reid and Wood 1976). Chronic low runoff flows could also be associated with reduced carrying capacity as habitat niche abundance and diversity are reduced in the Big Hole River.

Extremely high summer water temperatures continued through the $2002-2004$ report period. Oswald (2002) noted very high water temperatures over the $2000-2001$ water years and associated extremely high water temperatures at stations downstream from Glen, Montana with maximum observed brown trout population declines in the Hog Back Section. The 2003 Water year exhibited extremely high daily thermal maxima, minima, and means for the months of July and August with water temperatures attaining or exceeding 21.1 degrees C. (70.0 degrees F.) on 34 days. July and August Water temperatures in 2003 exceeded highs observed in the current drought influenced episode as well as any of 1985 - 1994 drought affected years. Ambient air temperatures at the Dillon Station averaged 70.8 and 69.0 degrees F in July and August 2003 representing 5.9 and 5.0 increases over the long term averages for those respective months (National Weather Service, Great Falls). Thermal trends over the 2000 - 2004 period have remained far above average and have probably interacted with low flow regimes as well as other habitat parameters to reduce trout carrying capacity across all of the current study reaches. Oswald (1979) demonstrated that elevated thermal regimes resulted in significant reductions in the standing crops of aquatic macroinvertebrates in thermally enriched gradients. The affects of 
thermal interaction with chemical parameters, particularly oxygen, has been discussed in detail regarding macroinvertebrate communities by Krenkal and Parker (1969), Vernberg and Vernberg (1974) and Oswald (1979). Oswald (2002) noted that the additional thermal input, despite flow mitigation efforts of the Big Hole River Drought Plan, was possibly associated with declining brown trout standing crop and declining numbers of older larger brown trout, particularly in lower river environs. Despite extremely stressful thermal conditions prevalent in 2003 and 2004, no thermally induced localized fish kills were documented in the Big Hole River over that period. Such kills accompanied prior drought episodes in 1988 (Vincent et al. 1989) and in 1994 (Byorth 1995). Oswald (2000a) noted other indications of stress such as reduced yearling rainbow trout growth, reduced condition factor in mature brown and rainbow trout, and fungal disease outbreaks during prior drought episodes. Some of these indications of stress, particularly reduced condition factor, were also noted during the 2000 - 2001 sample period.

\section{$\underline{\text { Rainbow Trout Populations }}$}

The rainbow trout population of the Jerry Creek Study Section demonstrated a decreasing trend over the 2002 - 2004 sample period. The decreases, however, were limited to declines in population density and juvenile recruitment. Rainbow trout standing crop remained relatively stable at slightly above average levels for the study section. Rainbow trout standing crop was supported by relatively robust densities of older, larger fish in the population despite prevailing drought conditions. Oswald (2002) reported that direct comparisons with prior drought episodes strongly suggested that components of the Big Hole River Drought Plan have significantly benefited rainbow trout populations. These benefits have been most substantially manifest as improvements in standing crop and densities of older, larger fish in the population. Data from the current report period continue to support that assumption. Oswald (2000a, 2000c, and 2003) noted numerous examples of expansion of brown and rainbow trout standing crops and densities of mature fish in populations in the Big Hole, Beaverhead, and Ruby Rivers under conditions of ample streamflow. He also noted the decrease in these key parameters under low flow regimes associated with drought conditions. Oswald (2002) also postulated that moderate spring runoff flows such as those experienced in 2000 and 2001 were associated with relatively strong recruitment classes of yearling rainbow trout. Conversely, Oswald (2000a) suggested that high runoff peaks ranging between 11,300 and $12,800 \mathrm{cfs}$ during the $1995-1997$ period resulted in very poor recruitment of yearling rainbow trout into the population over the $1996-1998$ period. Improved recruitment under moderate spring runoff flows might be a manner in which rainbow trout populations appear to avoid some of the severe affects of low flow experienced in the brown trout populations. If this pattern is continued, the spring of 2004 should result in relatively strong recruitment of Age I rainbow trout in 2005. A third factor which could be influencing rainbow trout survival in upper river reaches typified by the Jerry Creek Section might be improved streamflow from accretions and improved thermal regimes concomitant with improved streamflow. These factors were noted by McGuire (2003) in an assessment of macroinvertebrate communities of different stations throughout the Big Hole River. Stations at the Jerry Creek Bridge and Dickie Bridge upstream were found to be slightly impaired to unimpaired, respectively, by drought influenced parameters. Finally, the role of special restrictive angling 
regulations in the face of low flow conditions was discussed by Oswald (2002) with additional consideration of analysis by other authors (Kozakiewicz (1979), Wells and Decker-Hess (1980), Avery and Hunt (1981), Oswald (1986), Vincent et al. 1989, Oswald 2000a). This discussion led to the conclusion that carrying capacity and recruitment and natural mortality rates, under varying habitat conditions, probably are more important in dictating recent rainbow trout population trends than special restrictive regulations on the Big Hole River.

In addition to the affects of chronic low flows, rainbow trout populations in the Melrose Section appear to be declining with chronic poor recruitment. Prior whirling disease data collected from various reaches of the Big Hole River had been indicative of a low frequency of infected fish within the population and a low grade of infection in the fish that have been infected (Oswald 2002). The recent discovery of a point source of whirling disease in a drain ditch effluent appears to be directly linked to the rainbow trout population declines in the Melrose Section river reach. Studies in 2003 and 2004 have identified the source of the infection as particularly virulent, resulting in high infection rates and severe levels of infection in rainbow trout swim - up fry exposed to the infection in test cages. While the average histology for test cages in the drain ditch and Camp Creek ranged from 4.88 to 5.00, a downstream test cage in the Big Hole River yielded an average histology of 3.89. Average infection rates of 2.75 have resulted in significant declines in rainbow trout recruitment while individual rainbow trout fry exposed to infection levels of grade 3.00 or higher usually do not survive (Vincent et al. 2005). When caged rainbow trout fry all exceed grade 3.00 infections, mortality rates approach $100 \%$ and, when an average infection of 3.89 is encountered, very few fish have infection grades lower the 3.00 (Vincent et al. 2005). Future whirling disease research in the Melrose Section vicinity will be directed toward the potential to eliminate or reduce the source of the disease and future rainbow trout population research directed toward recovery of normal recruitment rates and the rainbow trout population.

\section{Brown Trout Populations}

The brown trout populations of the Big Hole River declined substantially over the 2002 2005 sample period. Oswald (1986), Vincent et al. (1989), and Oswald (2000a) all discussed the affects of flow on Big Hole River brown trout populations and Oswald and Brammer (1993), and Oswald (2000c and 2003)) documented the affects of low flows on numbers of large brown trout in the Beaverhead and Ruby Rivers. The $2002-2004$ flow regimes continued a drought influenced pattern that has persisted since late summer of 1999. Brown trout population parameters such as density, standing crop, density of older, larger fish, and condition factor all declined or remained relatively stable at low levels, however, many of these parameters maintained at levels above those observed in the prior drought episode 1985 - 1994. Oswald (2002) suggested that this improved brown trout population response was attributed to beneficial components of the Big Hole River Drought Plan, particularly improvement of low flow regimes and reduction of human caused stress to the population. Population declines since then, however, were probably related to the long term persistence of low flow conditions and extremely high summer water temperatures that marked the current report period. Thus, the persistence and severity of the current drought episode continue to be more difficult to mitigate.

In contrast with rainbow trout recruitment, brown trout recruitment has fared poorly 
under low flow conditions. This might be due to differences between spring and fall spawning conditions under low flow regimes but might also be influenced by the fact that brown trout recruitment is assessed from spring Age II fish while rainbow trout recruitment is assessed from fall Age I fish. Thus, the brown trout recruits have to survive another winter at low flow prior to their inclusion in population estimates.

Brown trout spring condition factor $(\mathrm{K})$ appeared to be reduced by low flow regimes in both the Melrose and Hog Back Sections. This relationship was more pronounced in the Hog Back Section. Oswald (2002) felt that larger declines in the Hog Back brown trout populations than those observed in upstream study sections were associated with more severe summer thermal conditions in lower river reaches. Conversely, extremely warm winter temperatures in $2004-$ 2005 probably affected brown trout condition factor in 2005 and might have influenced overwinter survival of older fish, particularly in the Hog Back Section. The relationship between spring brown trout condition factor and low flow intensified for the older, larger fish in the population. This same relationship has been observed for brown trout populations in the Beaverhead and Ruby Rivers (Oswald 2003). Mature brown trout are probably most susceptible to reductions in condition because stressful fall spawning activity is followed by severe winter conditions which most certainly have been exacerbated by low flow conditions. Large brown trout also generally require more habitat niche and energy intake than smaller fish, the availability of which is reduced under low flow conditions.

Oswald (2000a) discussed in detail the affects of special angling regulations applied within the Divide to Melrose reach since 1981 for brown and rainbow trout. The special regulations included a bag limit reduction, a "slot limit" under which trout between 13.0 and 22.0 inches in length had to be released, and a gear restriction to artificial lures. He reported on early increases in the number of 13 inch and 18 inch and larger brown trout following implementation of the special regulations but, in 1989 , observed that little difference existed between the two sections in terms of 13 inch and larger fish (Vincent et al. 1989). Oswald (2000a) further noted that any differences for 18 inch and larger brown trout among study sections, with or without special regulations, had become virtually undetectable since 1995. Clark and Alexander (1984) noted a decline in total brown trout numbers and a decline in the numbers of brown trout protected under a "slot limit" regulation on the Au Sable River in Michigan but did not observe a concomitant increase in large fish. The $2002-2005$ samples revealed depressed numbers of Age $\mathrm{V}$ and older brown trout in the Maiden Rock, Melrose and Hog Back study sections at densities approximating 40 fish per mile despite the absence of special regulations in the Melrose and Hog Back Sections. Moreover, the 2004 estimate of these 18 inch and larger brown trout in the Maiden Rock Section was the lowest observed since 1981 prior to the implementation of the special regulations. The data strongly suggest that restrictive angling regulations do not mitigate the prevailing affects of habitat degradation associated with low flow regimes and high summer water temperatures. Oswald (2002) concluded that highs in densities of larger fish in the Big Hole River and other southwest Montana streams were attained under optimal habitat conditions while lows were observed under the reduced carrying capacities associated with low flow conditions regardless of the presence or absence of special regulations. 


\section{LITERATURE CITED}

Avery, E. L. And R. Hunt 1981. Population dynamics of wild brown trout and associated sport fisheries in four central Wisconsin streams. Tech. Bull. 121, Wis Dept. Nat. Res. 28pp.

Brittain, S., M. Lere, and B. McFarland. 1997. Mark / Recapture estimate guidelines for Montana. Fish. Inf. Services Bull., Mont. Dept. Fish, Wild \& Parks, Bozeman 20pp.

Byorth, P.A. 1991. Population surveys and analysis of fall and winter movements of arctic grayling in the Big Hole River: 1991 annual report. Fluv. Arc. Grayling Workgroup. Mont. Dept. Fish, Wild. \& Parks, Bozeman.

1993. Big Hole River arctic grayling recovery project: annual monitoring report 1992. Fluv. Arc. Grayling Workgroup, Mont. Fish, Wild. \& Parks, Bozeman.

1994. Big Hole River arctic grayling recovery project: annual monitoring report 1993. Fluv. Arc. Grayling Workgroup, Mont. Dept. Fish, Wild. \& Parks, Bozeman.

1995. Big Hole River arctic grayling recovery project: annual monitoring report 1994. Fluv. Arc. Grayling Workgroup, Mont. Dept. Fish, Wild. \& Parks, Bozeman.

1996. Big Hole River arctic grayling recovery project: annual monitoring report 1995. Fluv. Arc. Grayling Workgroup, Mont. Dept. Fish, Wild. \& Parks, Bozeman.

Clark, R.D. and G.R. Alexander. 1984. Effects of a slotted size limit on the brown trout fishery of the Au Sable River, Michigan. Fish. Res. Rpt. No. 1927, Mich. Dept. Nat. Res. 32pp.

Hunter, C.J. 1991. Better trout habitat, a guide to stream restoration and management. Island Press, Washington, D.C. 319pp.

Kozakiewicz, V.J. 1979. Trout fishery of the lower Big Hole River, Montana during 1977 and 1978. M.S. Thesis, Mont. St. Univ., Bozeman, 74pp.

Krenkal, P.A. and F.L. Parker 1969. Engineering aspects, sources, and magnitude of thermal pollution. Vanderbilt Univ. Press. 407pp.

Lamothe, P. and J.P Magee. 2003. Movement and habitat selection of Arctic grayling, brook trout, and mountain whitefish during drought conditions in the Big Hole River, Montana. Montana Arctic Grayling Workgroup.

2004. Linking Arctic grayling abundance to physical habitat parameters in the upper Big Hole River, Montana. Montana Arctic Grayling Workgroup. 
Liknes, G.A. 1981. The fluvial arctic grayling, Thymallus arcticus, of the upper Big Hole River drainage, Montana. M.S. Thesis, Mont. St. Univ., Bozeman, 59pp.

Magee, J.P. and P.A. Byorth 1998. Big Hole River arctic grayling recovery project: annual monitoring report 1997. Fluv. Arc. Grayling Workgroup, Mont. Dept. Fish, Wild \& Parks, Bozeman.

Magee, J.P. 1999. Big Hole River arctic grayling recovery project: annual monitoring report 1998. Fluv. Arc. Grayling Workgroup, Mont. Dept. Fish, Wild., \& Parks, Bozeman.

2002. Montana fluvial Arctic grayling recovery project: monitoring report 2000 - 2001. Fluv. Arc. Grayling Workgroup, Mont. Dept. Fish, Wild. \& Parks, Bozeman. 65pp.

Magee, J.P. and P.J. Lamothe. 2003. Montana fluvial Arctic grayling recovery project: monitoring report 2002. Fluv. Arc. Grayling Workgroup, Mont. Dept. Fish, Wild. \& Parks, Bozeman. 37pp.

2004. Montana fluvial Arctic grayling recovery project: monitoring report 2003. Fluv. Arc. Grayling Workgroup, Mont. Dept. Fish, Wild. \& Parks, Bozeman. 26pp.

McGuire, D. L. 2003. Macroinvertebrate - based assessment of the big Hole River, Montana, August 2002. Report prepared for the Big Hole River Foundation, Butte, MT 23pp.

Montana Fish, Wildlife \& Parks. 1989. Application for reservations of water in the Missouri River basin above Fort Peck dam. Vol. 2., Mont. Dept Fish, Wild. \& Parks, Helena 620pp. 1991 - 1999. Montana statewide angling pressure estimates. Fish. Inf. Services, Mont. Dept. Fish, Wild. \& Parks, Bozeman

1994. Mark / Recapture version 4.0, a software package for fishery population estimates. Fish. Inf. Services, Mont. Dept. Fish, Wild. \& Parks, Bozeman 45pp.

Nelson, F. A. 1980. Guidelines for using the wetted perimeter (WETP) computer program of the Montana Department of Fish, Wildlife and Parks. Mont. Dept. FWP, Bozeman MT 23pp.

1980a. Evaluation of four instream flow methods applied to four trout rivers in southwest Montana. Mont. Dept. FWP, Bozeman, MT. 105pp.

Oswald, R.A. 1979. Observations of aquatic macroinvertebrates in natural thermal gradients. M.S. Thesis, Dept. of Biology, Montana State Univ. Bozeman, MT 137pp.

1984. Inventory and survey of the waters of the Big Hole and Ruby River drainages. Job Prog. Rpt., Fed Aid in Fish and Wild Rest. Acts. Mont. Proj. No. F-9-R- 
31-32, Job No. Ib, 23 pp.

1986. Inventory and survey of the waters of the Big Hole, Beaverhead, and Ruby River drainages. Job Prog. Rpt,., Fed. Aid in Fish and Wild. Rest. Acts. Mont. Proj. No. F-9-R34, Job No. Ib, 35pp.

2000a. Inventory and survey of the salmonid populations of the Big Hole River of southwest Montana, 1981 - 1999. Job Prog, Rpt., Fed Aid in Fish and Wild. Rest. Proj. Nos. F-78-R-1,2,3,4, and 5. 32pp.

2000b. Inventory and survey of selected stream fisheries of the Red Rock, Ruby, and Beaverhead River drainages of southwest Montana. Job Prog. Rpt., Fed. Aid in Fish and Wild. Rest. Proj. Nos. F-78-R-1,2,3,4, and 5. 75pp.

$2000 \mathrm{c}$. Inventory and survey of fish populations in lowland lakes and reservoirs of the Red Rock, Ruby, Beaverhead, and Big Hole River drainages of southwest Montana. Job Prog. Rpt., Fed. Aid in Fish and Wild. Rest. Proj. Nos. F-78-R-1,2,3,4, and 5. 50pp.

2002. Inventory and survey of the salmonid populations of the Big Hole River of southwest Montana, 2000 - 2001. Job Prog, Rpt., Fed Aid in Fish and Wild. Rest. Proj. Nos. F-78-R-6 and F-113-R-1. 26pp.

2003. Inventory and survey of selected stream fisheries of the Red Rock, Ruby, and Beaverhead River drainages of southwest Montana; 2000-2002. Job Prog. Rpt., Fed. Aid in Fish and Wild. Rest. Proj. Nos. F-78-R-6, F-113-R-1 and R-2. 71 pp.

Oswald, R.A. and J.A. Brammer 1993. Survey of the trout populations of the Beaverhead River and selected tributaries within its drainage. Job. Prog. Rpt., Fed. Aid in Fish and Wild. Rest. Acts. Mont. Proj. No. F-46-R-6, Job Nos. Ie and If, 51 pp.

Oswald, R.A. and B. Roberts 1998. Twin Lakes fish population sampling. Rpt. To Big Hole Watershed Com., Mont. Dept. Fish, Wild. \& Parks, Dillon 13pp.

Reid, G. K. and R. D. Wood 1976. Ecology of inland waters and estuaries. D. Van Nostrand Co. ISBN : 0-442-17605-8. 485pp.

USGS, 1989-2001. Water resources data for Montana, Water Years 1989 - 1999. U.S. Geological Survey, annual water resources reports for Montana.

Vernberg, F.J. and W.B. Vernberg Synergistic effects of temperature and other environmental parameters on organisms. Pages $94-99$ in Gibbons, J.W. and R.R. Sharitz, eds. Thermal 
ecology, proceedings of a symposium at Augusta, Ga. USAEC

Vincent, E.R. 1971. River electrofishing and fish population estimates. Prog. Fish Cult. 33(3):163-167.

Vincent, E.R., C. Clancy, W. Fredenberg, R. Oswald, and B. Rehwinkle. 1989. Southwest Montana major river fisheries investigations. Job Prog. Rpt., Fed Aid in Fish and Wild. Rest. Acts, Proj. No. F-46-R-2, Job No. If, 59pp.

Vincent, E.R., P. Clancey, and J Tohtz. 2005. Possible reasons for increased survival of young-of-the-year wild rainbow trout in the face of continued high prevalence of the WD parasite Myxobolus cerebralis in the upper Madison River. Proceedings of the Whirling Disease Symposium, February 2005, Denver, CO. 5pp.

Warren, J.W. 1991. Diseases of hatchery fish. U.S. Fish and Wildlife Service. Pacific Region. Sixth Edition. 90pp.

Wells, J.D. and J. Decker-Hess 1980. Inventory and survey of the waters of the Big Hole, Ruby and Beaverhead River drainages. Job Prog. Rpt., Fed. Aid in Fish and Wild. Rest. Acts, Proj. No. F-9-R-28, Job No. Ib, 35pp.

Report Prepared By: Richard A. Oswald, MFWP, Region 3, Bozeman June 2005

All Work Included in this Report in Conjunction with Federal Aid in Fish and Wildlife Restoration Acts:

Project Numbers: F-113-R-2, R-3, R-4, and R-5

Montana Fish, Wildlife \& Parks Project Number 3320 
APPENDIX OF FIGURES 
Figure 1. Anmual Water Yield (Acre Feet) for the Big

Hole River at the USGS Melrose Gage 1982 - 2004.

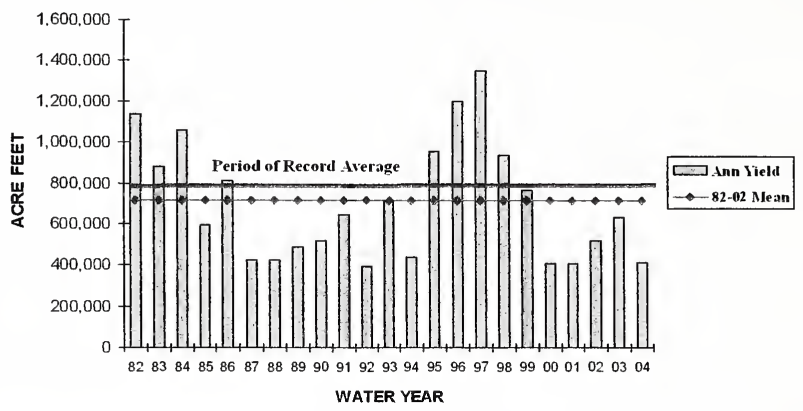

Figure 2. Peak spring runoff flows measured at the USGS Melrose Gage for the 1982 - 2004 period of record on the Big Hole River.

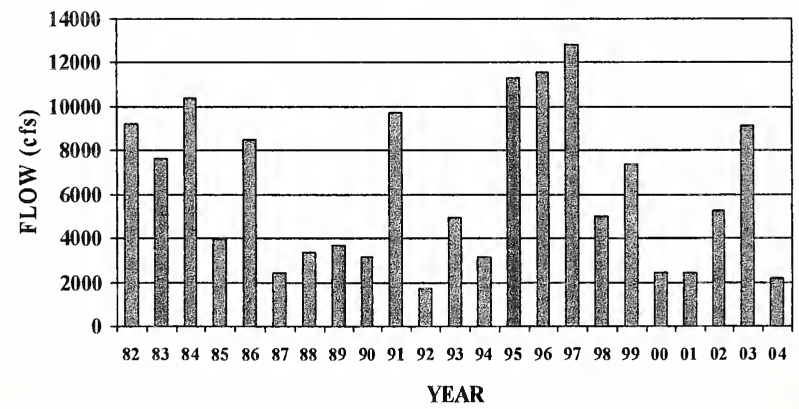


Figure 3. Mean August flow as compared with the FWP recommended optimum and minimum instream flow at the USGS Melrose Gage on the Big Hole River; 1982 - 2004.

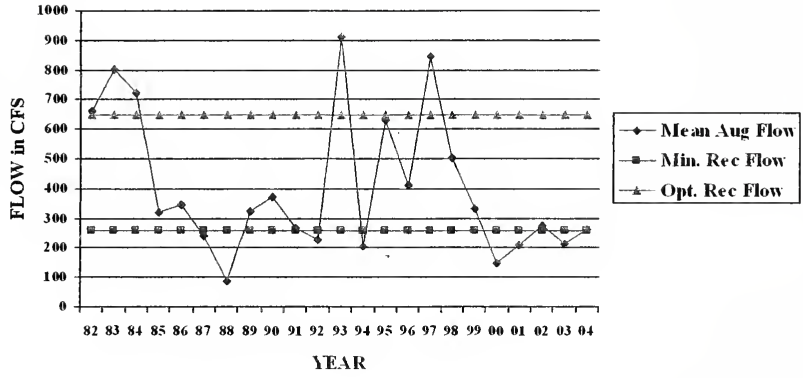

Figure 4. Minimum August flows (ADF) measured at the USGS Melrose Gage for the 1982 - 2004 period of record on the Big Hole River.

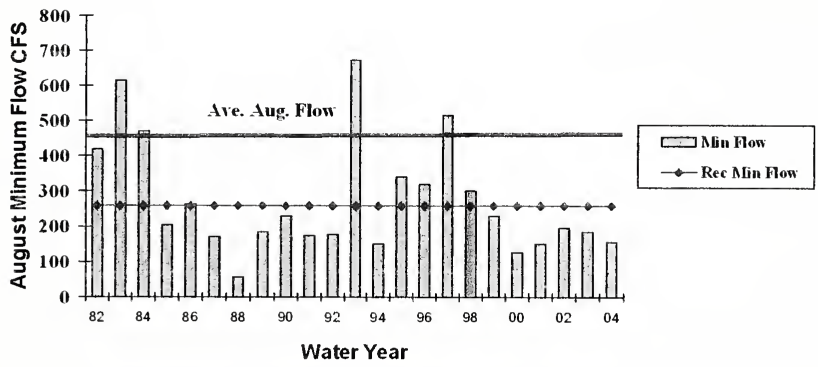


Figure 5. Maximum, Mean, and Minimum July temperatures recorded at the USGS Meirose Gage for the 1987 - 2004 period of record on the Big Hole River.

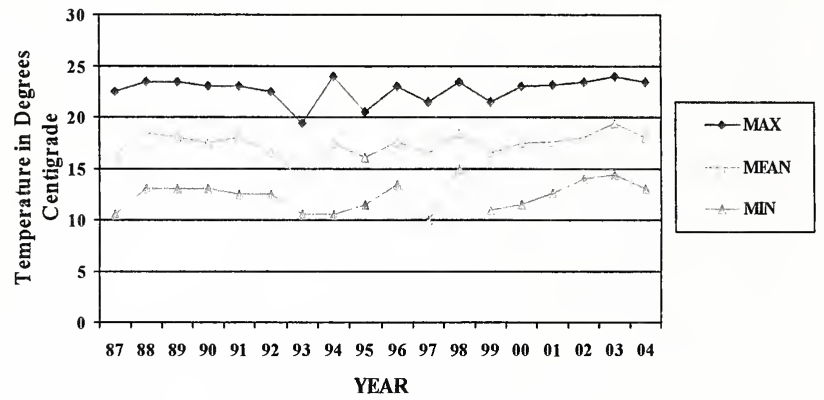

Figure 6. The number of days on which maximum water temperatures equaled or exceeded 70 degrees F (21.1 C) during the months of July and August at the USGS Melrose Gage for the $1987-2004$ period of record on the Big Hole River.

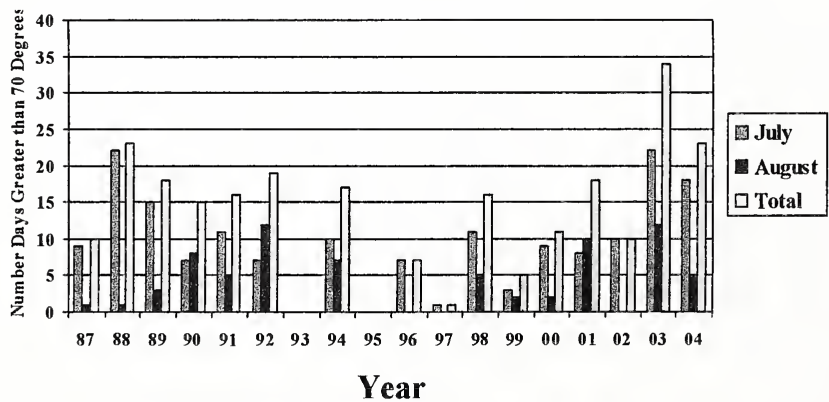


Figure 7. Estimated fall density and standing crop of Age I and older rainbow trout in the Jerry Creek Section of the Big Hole River, 1986 - 2004.

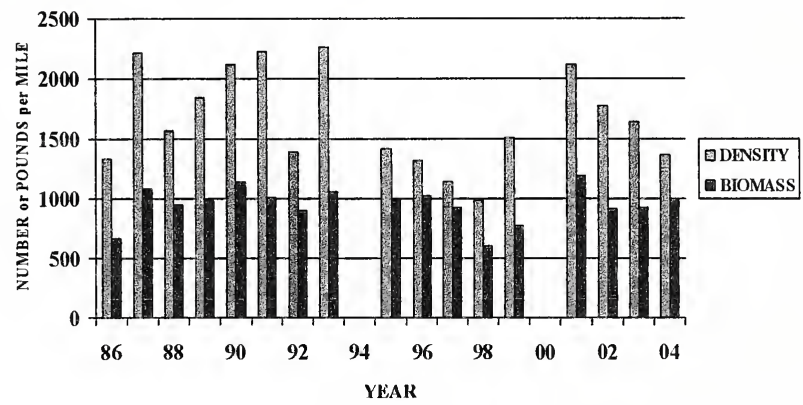

Figure 8. Estimated fall density of Age I rainbow trout in the Jerry Creek Section of the Big Hole River, 1986 - 2004.

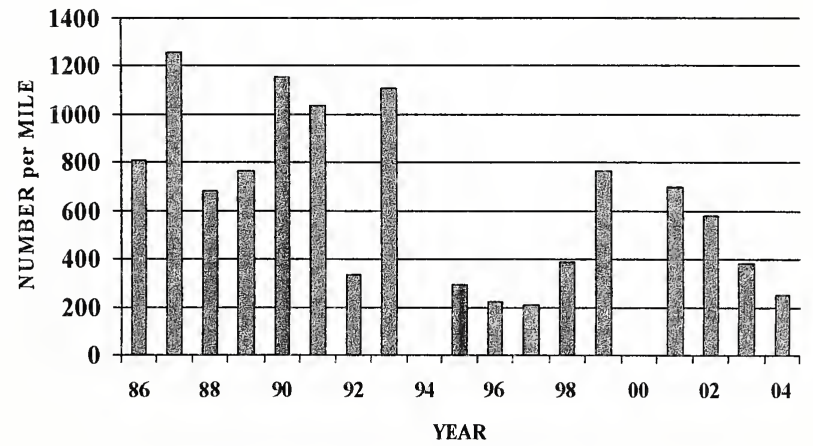


Figure 9. Estimated fall density of $\mathbf{1 3}$ inch and larger (Age III+) rainbow trout in the Jeny Creek Section of the Big Hole River 1986 - 2004.

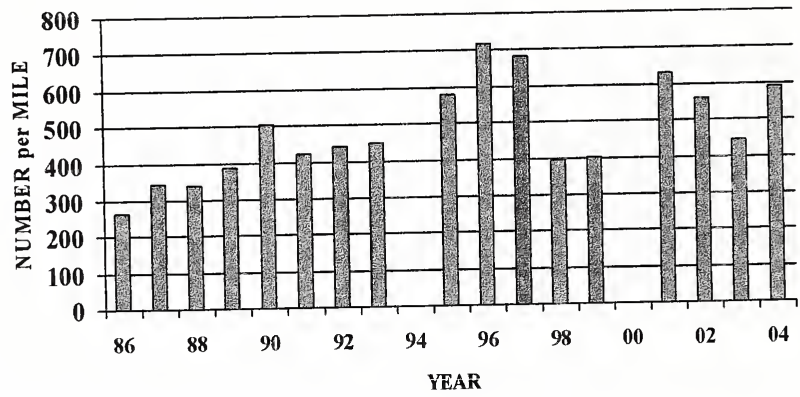

Figure 10. Estimated fall density of 16 inch and larger $($ Age $\mathrm{V}+$ ) rainbow trout in the Jeny Creek Section of the Big Hole River, 1986 - 2004.

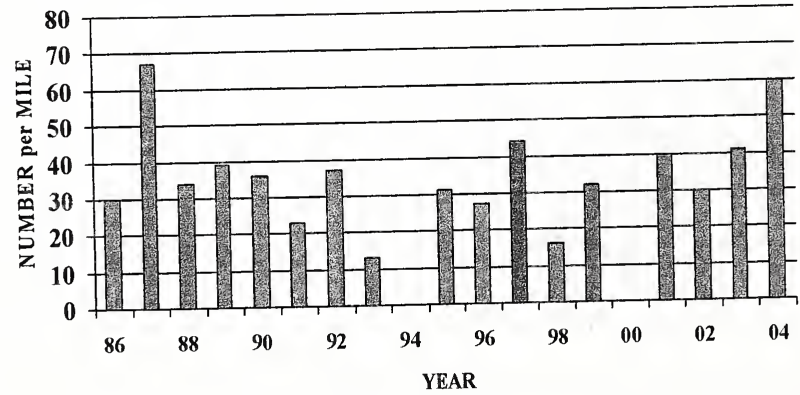


Figure 11. Estimated fall density and standing crop of Age $I$ and older rainbow trout in the Melrose Section of the Big Hole River, 1981 - 2004.

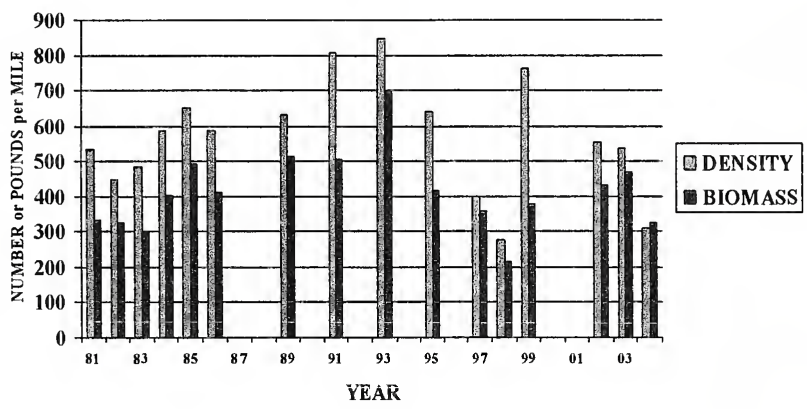

Figure 12. Estimated fall density of Age I rainbow trout in the Melrose Section of the Big Hole River, 1981 - 2004.

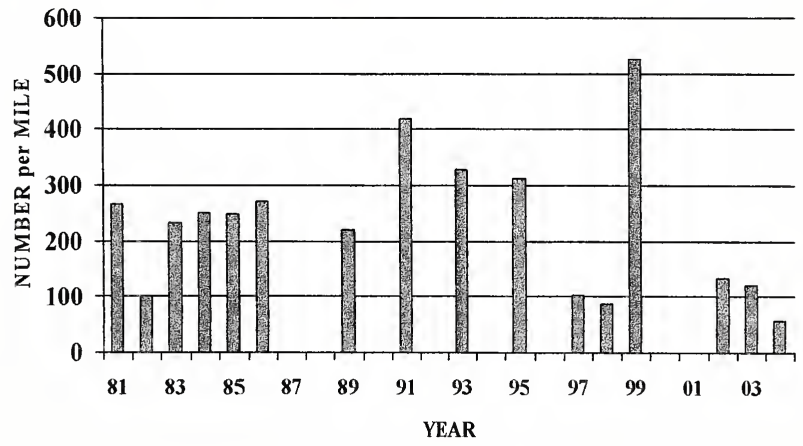


Figure 13. Estimated fall density of 13 inch and larger

(Age III+) Rainbow Trout in the Melrose Section of the Big Hole River, 1981 - 2004.

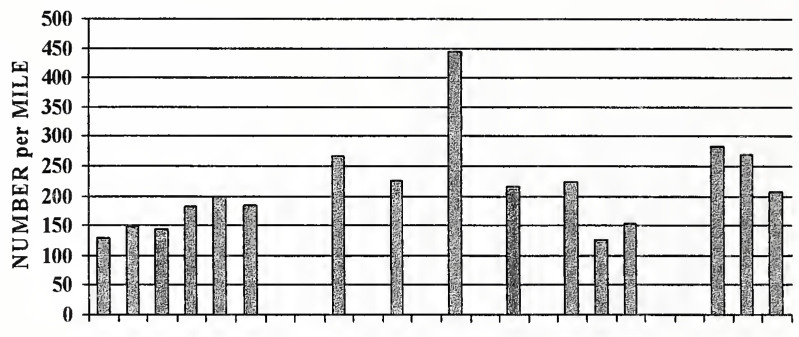

$8182838485868788 \quad 99909192939495969798990001020304$ YEAR

Figure 14. Estimated fall density of $\mathbf{1 6}$ inch and larger $($ Age $\mathrm{V}+$ ) rainbow trout in the Melrose Section of the Big Hole River, 1981 - 2004.

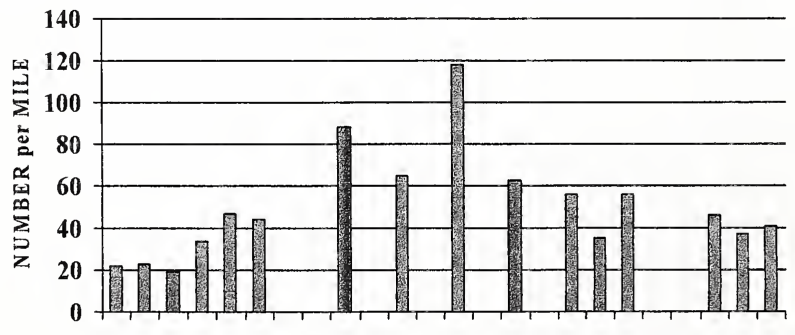

818283848586878889909192939495969798990001020304

YEAR 
Figure 15. Estimated spring density and standing crop of Age II and older brown trout in the Maiden Rock Section of the Big Hole River 1981 - 2004.

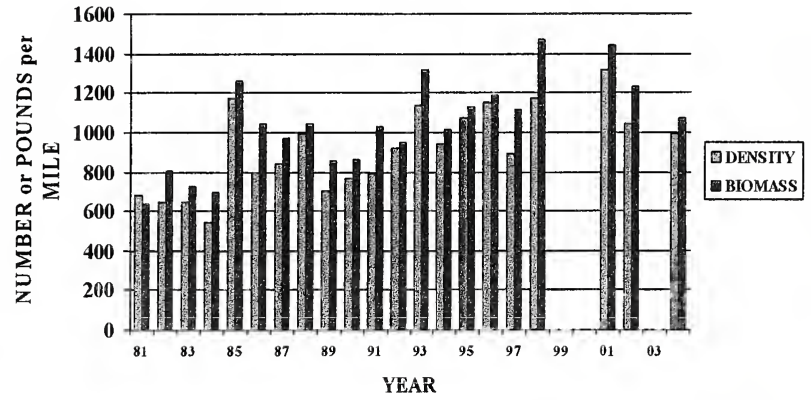

Figure 16. Estimated spring density of 13 inch and larger (Age III+) brown trout in the Maiden Rock Section of the Big Hole River, 1981 - 2004.

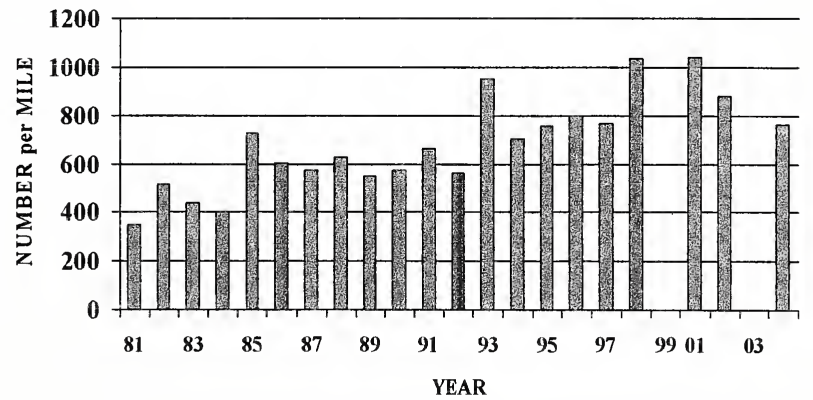


Figure 17. Estimated spring density of 18 inch and larger (Age V+) brown trout in the Maiden Rock Section of the Big Hole River, 1981 - 2004.

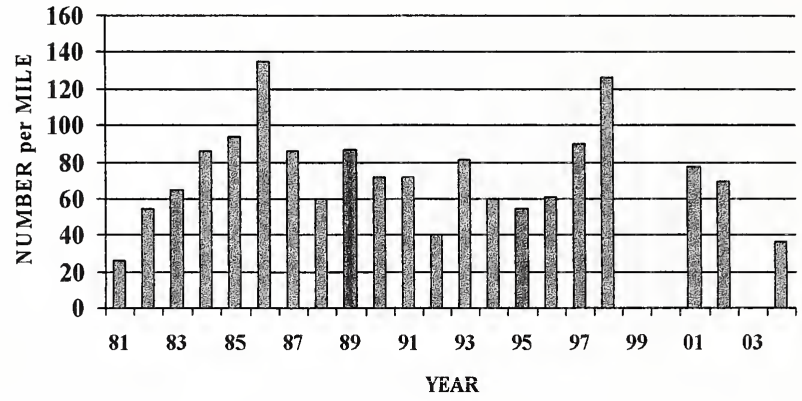

Figure 18. Estimated spring density and standing crop of Age II and older brown trout in the Melrose Section of the Big Hole River, 1981 - 2005.

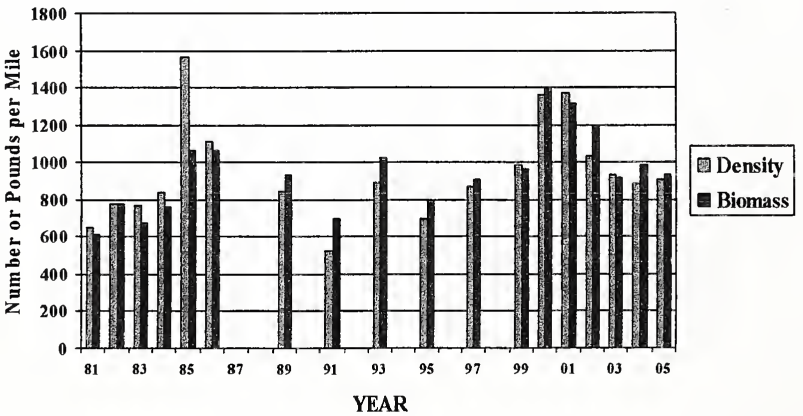


Figure 19. Estimated spring density of Age $I /$ brown trout in the Melrose Section of the Big Hole River 1981 $~ 2005$.

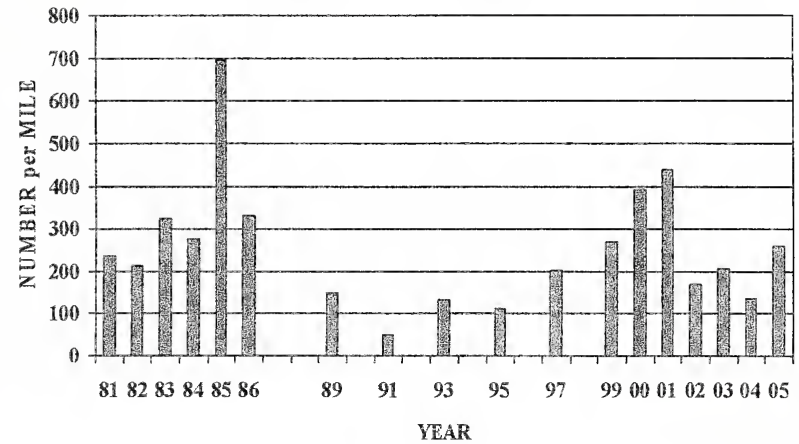

Figure 20. Estimated spring density of 13 inch and larger (Age IIH + ) brown trout in the Melrose Section of the Big Hole River 1981 - 2005.

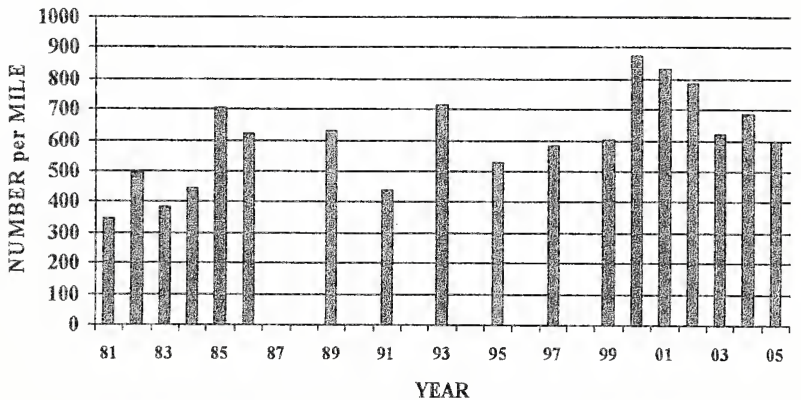


Figure 21. Estimated spring density of 18 inch and larger (Age $\mathbf{V}+$ ) brown trout in the Melrose Section of the Big Hole River, 1981 - 2005.

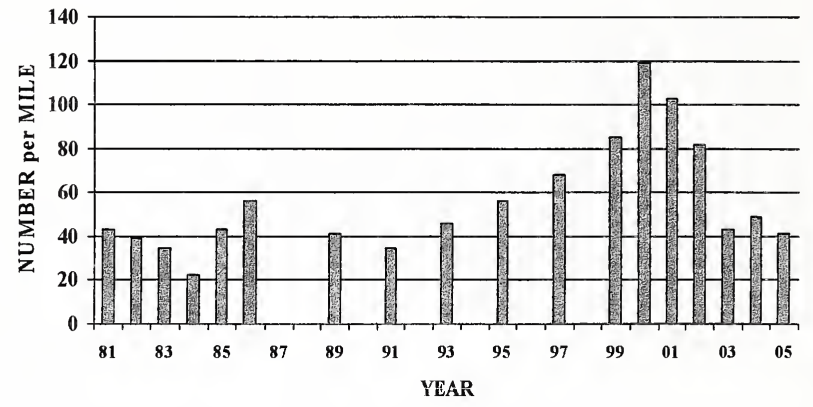

Figure 22. Mean spring Condition Factor $(K)$ for total brown trout, 15.0 to 17.9 inch brown trout (Age IV+), and 18.0 inch and larger brown trout (Age $\mathrm{V}+$ ) collected in the Melrose Section of the Big Hole River 1993 - 1997 vs. 2001 - 2003 and 2005.

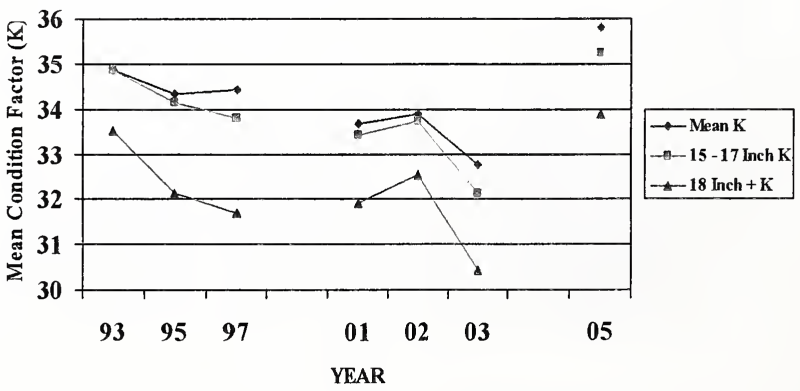


Figure 23. Estimated spring density and standing crop of Age II and older brown trout in the Hog Back Section of the Big Hole River, 1987 - 2005.

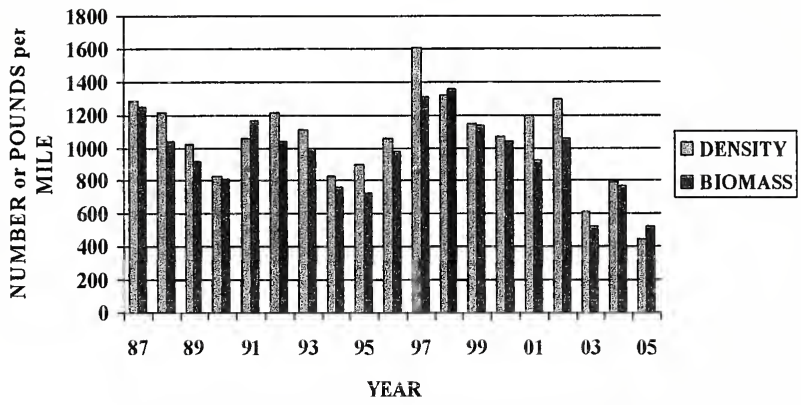

Figure 24. Estimated spring density of Age II brown trout in the Hog Back Section of the Big Hole River $1987-2005$.

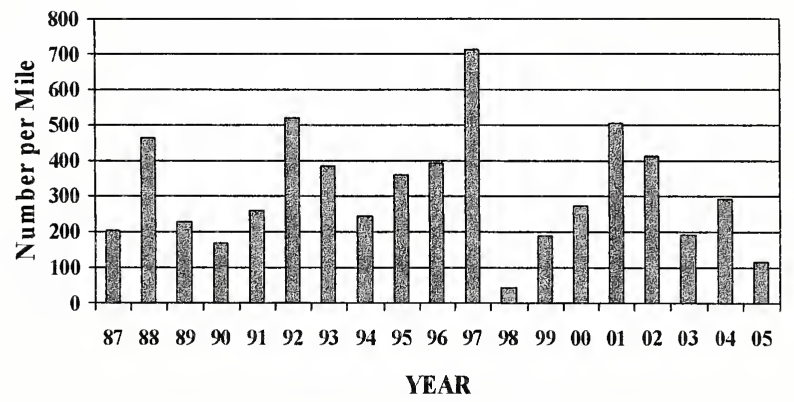


Figure 25. Density of Age II versus Age $\mathrm{V}$ and older (18 inch plus) brown trout in the Hog Back Study Section of the Big Hole River, 1998 - 2003.

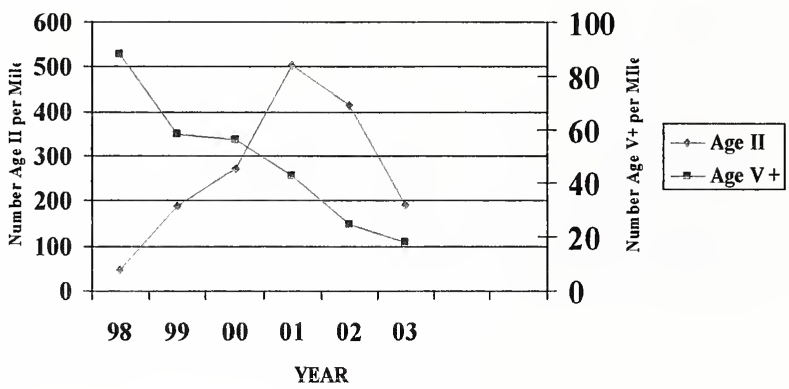

Figure 26. Estimated spring density of 13 inch and larger (Age III+) brown trout in the Hog Back Section of the Big Hole River, 1987 - 2005.

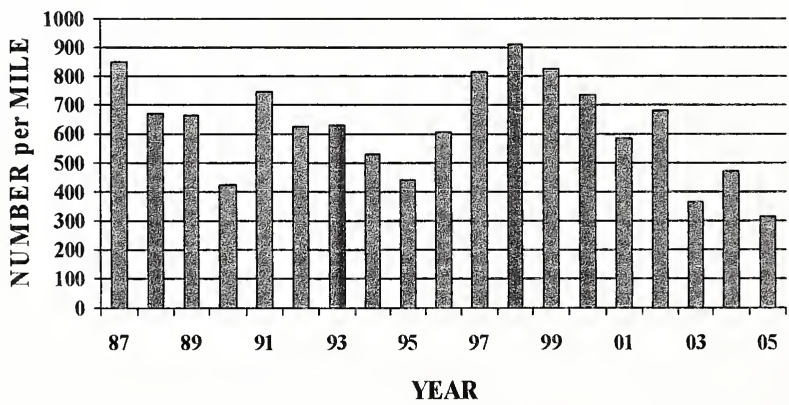


Figure 27. Estimated spring density of $\mathbf{1 8}$ inch and larger

$($ Age $\mathrm{V}+$ ) brown trout in the Hog Back Section of the Big Hole River, 1987 - 2005.

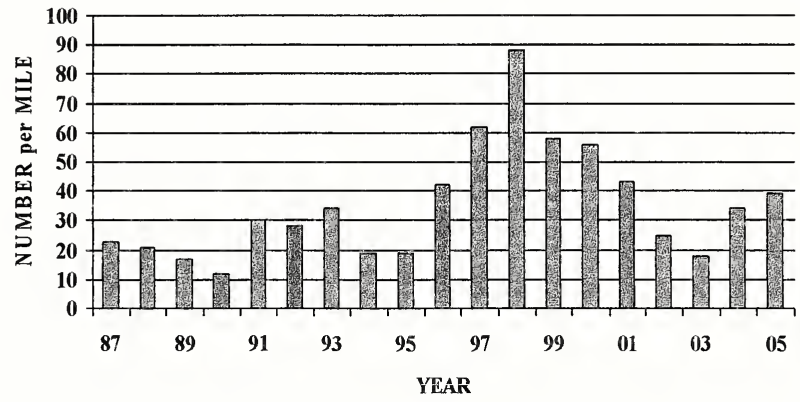

Figure 28. Mean spring Condition Factor (K) for total brown trout, 15.0 to 17.9 inch brown trout (Age IV+), and 18.0 inch and larger brown trout (Age $\mathrm{V}+$ ) collected in the Hog Back Section of the Big

Hole River 1995 - 1998 vs. 2000 - 2003 and 2005.

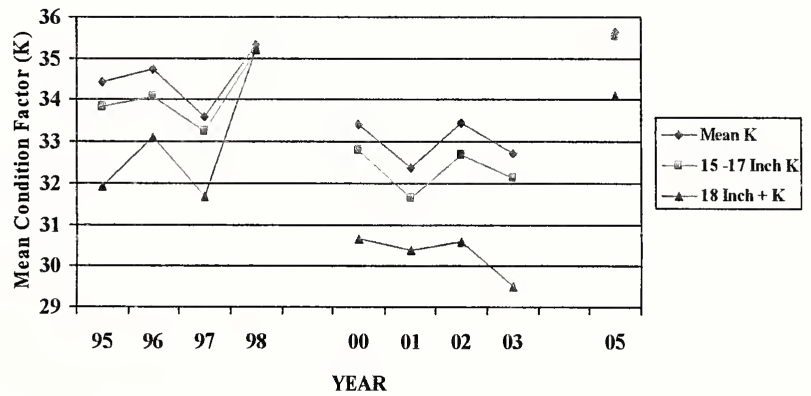




